\title{
Meconium Induces Only Localized Inflammatory Lung Injury in Piglets
}

\author{
KALLE KORHONEN, HANNA SOUKKA, LAURI HALKOLA, HEIKKI PEURAVUORI, \\ HEIKKI AHO, KARI PULKKI, PENTTI KERO, AND PEKKA O. KÄÄPÄ \\ Research Centre of Applied and Preventive Cardiovascular Medicine (CAPC) [K.K., L.H., P.O.K.], \\ Department of Pediatrics [H.S., P.K.], Department of Pathology [H.P., H.A.] and Department of Clinical \\ Chemistry [K.P.], University of Turku, FIN-20520 Turku, Finland
}

\begin{abstract}
ABSTR
Neonatal meconium aspiration often produces severe respira-
tory distress due to an inflammatory pulmonary injury, but the
extension of this damaging reaction to the noncontaminated lung
regions is still uncertain. To investigate the presence of general-
ized pulmonary inflammatory response, 31 anesthetized and
ventilated neonatal piglets (1-3 d) were studied. Meconium $(n=$
16) or saline $(n=15)$ was instilled unilaterally into the right
lung, and analysis of the lung tissue or bronchoalveolar lavage
(BAL) fluid from both lungs was performed after 12 h. Meco-
nium increased the wet/dry weight ratio, histologic tissue injury
score and tissue myeloperoxidase activity as well as BAL fluid
total cell count in the contaminated lung. Tumor necrosis factor-
alfa concentrations in BAL fluid did not however differ signifi-
cantly. Furthermore, in the meconium-instilled lungs the tissue
and lavage fluid catalytic activity of phospholipase $\mathrm{A}_{2}$ (PLA $\mathrm{P}_{2}$ )
and tissue PLA ${ }_{2}$ group-I and group-II concentrations were sig-
\end{abstract}
Despite aggressive perinatal treatment, meconium aspiration syndrome (MAS) still remains a significant cause of morbidity and mortality in term and postterm infants (1). The clinical syndrome is characterized by fetal or neonatal aspiration of meconium leading to severe respiratory distress with hypoxemia in the newborn, and may be further complicated by air leaks, persistent pulmonary hypertension, hypoxic organ damage and long-term pulmonary sequelae (2). The pathophysiology of MAS is very complex, including early mechanical obstruction of the airways (3), surfactant inactivation $(4,5)$, ventilation/perfusion mismatch and progressively developing patchy lung injury with areas of atelectasis and hyperexpansion $(1,6,7)$. Aspirated meconium may directly damage the alveolar-capillary membrane and also frequently induces pulmonary inflammatory response, common to a variety of experi-

Received February 12, 2001; Accepted March 18, 2002.

Correspondence: Kalle Korhonen, M.D., Research Centre of Applied and Preventive Cardiovascular Medicine (CAPC), Kiinamyllynkatu 10, FIN-20520 Turku, Finland; e-mail: kalle.korhonen@utu.fi

The study was supported by the Foundation for Pediatric Research, Finland, Finnish Cultural Foundation and Sigrid Juselius Foundation.

DOI: 10.1203/01.PDR.0000072784.55140.1E nificantly elevated. Although BAL fluid catalytic activity of $\mathrm{PLA}_{2}$ was moderately increased also in the meconium noninstilled lung, significant inflammatory injury in this lung was absent. The results thus indicate that meconium aspiration induces severe local inflammation and lung injury, but significant generalized pulmonary inflammatory damage in the pathogenesis of meconium aspiration syndrome is unlikely. (Pediatr Res 54: 192-197, 2003)
Abbreviations
MAS, meconium aspiration syndrome
BAL, bronchoalveolar lavage
MPO, myeloperoxidase
TNF- $\alpha$, tumor necrosis factor alfa
PLA 2 , phospholipase $\mathrm{A}_{2}$

mental lung injury models $(8,9)$, that are proposed to contribute to the development of the clinical pulmonary dysfunction $(6,7)$.

Pulmonary inflammatory response with neutrophil accumulation, supposedly initiated by meconium-induced activation of alveolar macrophages (10), seems to be present already within a few hours of exposure to meconium $(6,7,11)$. Infiltration of activated neutrophils may initiate a cascade of events, including the release of reactive oxygen metabolites and production of inflammatory mediators, such as cytokines and lipid mediators $(12,13)$. This inflammatory reaction is associated with increased pulmonary vascular permeability, proteinaceous exudation into the alveolar spaces, inactivation of pulmonary surfactant and decrease in lung compliance, and may thus significantly contribute to the impairment of pulmonary function (6). In contrast to acid aspiration that rapidly leads to generalized inflammatory reaction potentiating the local injury $(14,15)$, the extension and significance of the pulmonary tissue inflammation in meconium aspiration is poorly known.

We hypothesized that, in addition to local damage, intrapulmonary meconium could induce also generalized pulmonary 
inflammatory injury. We therefore developed a newborn piglet model, in which unilateral lung injury was caused by local meconium instillation, and examined both lungs for signs of inflammation and injury.

\section{METHODS}

Animal preparation. Thirty-one newborn (1-3 d) piglets weighing 1.6 to $2.4 \mathrm{~kg}$ from 17 maternal animals were studied. Animals were sedated with diazepam $(1.5 \mathrm{mg} / \mathrm{kg})$ i.m., and anesthetized with sodium pentobarbital $(30 \mathrm{mg} / \mathrm{kg})$ i.v. Tracheotomy was performed, a 3.5 -mm internal diameter endotracheal tube was inserted with the distal tip located at least $1 \mathrm{~cm}$ proximal to the carina, and animals were placed on a pressurecontrolled neonatal mechanical ventilator (Baby Bird, Bird Productions Corp., Palm Springs, CA, U.S.A.). The initial respiratory settings were: Fraction of inspired oxygen $\left(\mathrm{FiO}_{2}\right)$ 0.21 , rate 30 breaths $/ \mathrm{min}$, peak inspiratory pressure (PIP) 20 $\mathrm{cmH}_{2} \mathrm{O}$ and positive end expiratory pressure (PEEP) $4 \mathrm{cmH}_{2} \mathrm{O}$. Anesthesia was maintained with a continuous i.v. infusion of sodium pentobarbital $(6 \mathrm{mg} / \mathrm{kg} / \mathrm{h})$. Paralysis was induced with pancuronium bromide $(0.3 \mathrm{mg} / \mathrm{kg})$ i.v. and maintained with a continuous infusion $(0.6 \mathrm{mg} / \mathrm{kg} / \mathrm{h})$. A polyethylene catheter was inserted through the umbilical or femoral artery into the descending aorta to obtain blood gas samples and to continuously measure the blood pressure.

Experiments were approved by the Committee of Animal Care in Research of the University of Turku. Animals were cared for in accordance to procedures outlined in the "Guide for the Care and Use of Laboratory Animals" (National Institutes of Health Publications No. 85-23).

Meconium preparation. Meconium was collected from the first stools of several healthy term human neonates. The samples were initially frozen and later pooled, lyophilized, and irradiated for sterility. Before the experiment meconium was diluted with sterile saline to a concentration of $65 \mathrm{mg} / \mathrm{mL}$.

Study protocol. After $1 \mathrm{~h}$ of stabilization a bolus $(1.5 \mathrm{~mL} / \mathrm{kg})$ of meconium $(n=16)$ or sterile saline $(n=15)$ was instilled into the lower lobe of the right lung. In a supine position, a roentgenopaque catheter was inserted through the intubation tube under fluoroscopic guidance into the right main bronchus, $2 \mathrm{~cm}$ distal from the bifurcation of the trachea. The piglets were then turned to the right lateral position, and meconium or saline was instilled slowly through the catheter. Remaining of meconium in the right lung was confirmed in preliminary roentgenographic studies by unilateral instillation of meconium mixed with barium, and in the present study macroscopically and histologically after each experiment. After $15 \mathrm{~min}$ of ventilation the animals were turned back to the supine position for the rest of the study. Oxygen was added, when necessary, to keep $\mathrm{PaO}_{2}>8 \mathrm{kPa}$ and ventilatory frequency adjusted to keep $\mathrm{PaCO}_{2}<5 \mathrm{kPa}$. Body temperature was maintained $>38^{\circ} \mathrm{C}$ with a radiant warmer and a heating blanket. Five percent glucose in saline was infused i.v. at $6 \mathrm{~mL} / \mathrm{kg} / \mathrm{h}$. After $12 \mathrm{~h}$ of follow-up animals were killed with an overdose of potassium chloride.

Tissue samples. Lung tissue wet/dry weight ratio measurement and histologic analysis were performed in nine piglets in the meconium and eight in the saline group. $2 \times 2 \mathrm{~cm}$ lung tissue samples were excised in a consistent manner from the lateral region of the lower lung lobes of both lungs, fixed in $10 \%$ buffered formalin, dehydrated, cleared and embedded in paraffin according to a routine process. Five- $\mu \mathrm{m}$ sections were stained with hematoxylin and eosin for light microscopic analysis. To determine the extent and severity of the lung tissue injury, a pathologist (H.A.) blinded to the grouping of the piglets examined the samples and assigned a score from 0 to 4 for three different characteristics: 1$)$ extension of leukocyte infiltration $(0=0 \%, 1=0 \%$ to $25 \%, 2=25 \%$ to $50 \%, 3=$ $50 \%$ to $75 \%, 4=75 \%$ to $100 \%), 2$ ) amount of intra-alveolar leukocytes $(0=$ none, $1=$ occasional, $2=$ several leukocytes in the alveoli, $3=$ alveoli almost full of leukocytes, $4=$ alveoli distended by tightly packed leukocytes), and 3) amount of exudative debris $(0=$ alveoli open, $1=$ exudate scarcely seen, 2 = exudate clearly visible, $3=$ alveoli almost full of exudate, $4=$ alveoli distended by exudate). The histologic lung injury score is the sum of these scores. Alveolar septal diameter was subsequently measured with a computer software. Five highpower fields from hematoxylin-eosin stained sections were viewed and an average from 50 measurements registered.

Bronchoalveolar lavage (BAL). BAL was performed in seven piglets in the meconium and seven the in the saline group. The heart and lungs were first removed en bloc. Both main bronchuses were alternately tied and lavage of both lungs was performed separately by instillation of $15 \mathrm{~mL}$ of $0.9 \%$ $\mathrm{NaCl} 3$ times to each lung and immediate aspiration. BAL fluid was centrifuged $\left(350 \mathrm{G},+4^{\circ} \mathrm{C}\right.$ for $\left.10 \mathrm{~min}\right)$ and total alveolar cell counts from cellular debris were performed in Bürker chamber. Differential cell counts were performed after cytocentrifugation and May-Grünwald-Giemsa staining. Supernatant was collected, frozen at $-70^{\circ} \mathrm{C}$, and later used for determinations of total protein concentration with biuret method as well as for biochemical measurements of tumor necrosis factor alfa concentration and catalytic activity of phospholipase $\mathrm{A}_{2}$.

Myeloperoxidase (MPO). As an indicator of activated neutrophils, MPO activity of the lung tissue was assayed spectrophotometrically after homogenization of the tissue specimen using a method, in which the enzyme catalyzes the oxidation of 3.3'.5..5'-tetramethylbenzidine by $\mathrm{H}_{2} \mathrm{O}_{2}$ to yield a blue chromogen with a maximum wavelength of $655 \mathrm{~nm}$ (16).

Tumor necrosis factor alfa (TNF- $\alpha)$. Pig TNF- $\alpha$ concentration in BAL fluid supernatant was measured with in vitro ELISA (Endogen, INC., Woburn, MA, U.S.A.) according to manufacturer's instructions. Absorbance was read at $450 \mathrm{~nm}$ on an EIA reader (Spectra II, Wallac, Turku, Finland) with a fitting statistical software (MultiCalc Advanced, version 2.4) to calculate the results.

Catalytic activity and concentrations of phospholipase A2 (PLA2). The catalytic activity of $\mathrm{PLA}_{2}$ in lung tissue and BAL fluid supernatant were measured according to a modified method described earlier $(17,18)$. Briefly, lung tissue specimens were homogenized in $50 \mathrm{mM}$ sodium acetate buffer $(\mathrm{pH}$ 5.0) with $1 \mathrm{M} \mathrm{NaCl}$ and 1 tablet of protease inhibitor cocktail (Complete by Boehringer), $1 \mathrm{~g}$ of lung tissue per $4 \mathrm{~mL}$ of buffer. Homogenized samples were centrifuged for $20 \mathrm{~min}$ at $1000 \mathrm{G}$, and the supernatant was separated and used for PLA 2 
catalytic activity assay. The substrate working solution for the assay was prepared by mixing unlabeled 1.2-dipalmitoylphosphatidylcholine (Sigma Chemical Co., St. Louis, MO, USA) with 1-palmitoyl-2- $\left[{ }^{14} \mathrm{C}\right]$-arachidonoylphosphatidylethanolamine (Dupont, Boston, MA, U.S.A.) in a ratio of 6 $\mathrm{mM}: 1.325 \mu \mathrm{M}(250 \mathrm{nCi})$, dissolved in a mixture of chloroform and methanol (2:1), dried under a flow of nitrogen, and redissolved in $10 \mathrm{~mL} 0.1 \mathrm{M}$ glycine buffer ( $\mathrm{pH}$ 8.1). Ten- $\mu 1$ samples of lung tissue supernatant or BAL fluid supernatant were then incubated with $100 \mu \mathrm{L}$ of substrate buffer for $3 \mathrm{~h}$ at $40^{\circ} \mathrm{C}$. The reaction was stopped by adding $100 \mu \mathrm{L}$ of Dole's reagent. Released $\left[{ }^{14} \mathrm{C}\right]$-arachidonic acid was segmented by $\mathrm{SiO}_{2} /$ water/heptane phase extraction, and detected by a liquid scintillation spectrometer (Wallac, Turku, Finland).

The concentrations of human $\mathrm{PLA}_{2}$ group I ( $\mathrm{PLA}_{2}-\mathrm{I}$, pancreatic type) and group II ( $\mathrm{PLA}_{2}$-II, synovial type) were measured in the supernatant of the homogenized lung tissue by time-resolved fluoroimmunoassays $(19,20)$. PLA 2 -I immunoassay uses MAb-coated microtitre plates and europium chelatelabeled polyclonal (rabbit) antibody as a tracer. Both antibodies were raised against purified human pancreatic $\mathrm{PLA}_{2}$. $\mathrm{PLA}_{2}$-II immunoassay utilizes a polyclonal antibody, raised in rabbits against human recombinant group II enzyme, both immobilized on the microtitre plate and also detecting tracer antibody. Fluorescence was measured with an Arcus fluorometer (Wallac, Turku, Finland).

Data analysis. Longitudinal data (mean arterial blood pressure and arterial oxygenation index) was first studied with the analysis of variance for repeated measures design, and posthoc comparisons between the groups were made with a nonpaired $t$ test. Significance between means of other data were first tested by analysis of variance for repeated measurements with one between factor (group) and one within factor (side). If significant differences were noted, a Bonferroni adjusted paired $t$ test was used to compare right and left lungs, and a nonpaired $t$ test to compare instilled and noninstilled lungs between the study groups. Association between variables was examined using the Pearson correlation test. A $p$-value $<0.05$ was considered statistically significant.

\section{RESULTS}

Mean arterial blood pressure decreased during the study period $(p<0.001)$, but there were no differences between the study groups (Fig. 1). The effect of time on arterial oxygenation index $\left(\mathrm{PaO}_{2} / \mathrm{FiO}_{2}\right)$ was significant $(p<0.001)$, and there was a significant group by time interaction $(p<0.001)$. The index was significantly lower in the meconium group during the first three hours, but later there were no differences between the groups (Fig. 1).

Intrapulmonary instillation of meconium resulted in increased wet/dry weight ratio, histologic injury score and MPO activity in the instilled lung, when compared with the contralateral lung (Table 1). Saline instillation had no significant effect on these parameters, although no difference in the wet/dry ratio was found between the meconium- and saline-instilled lungs. Alveolar septal diameter was similar in all the studied lungs (Table 1).
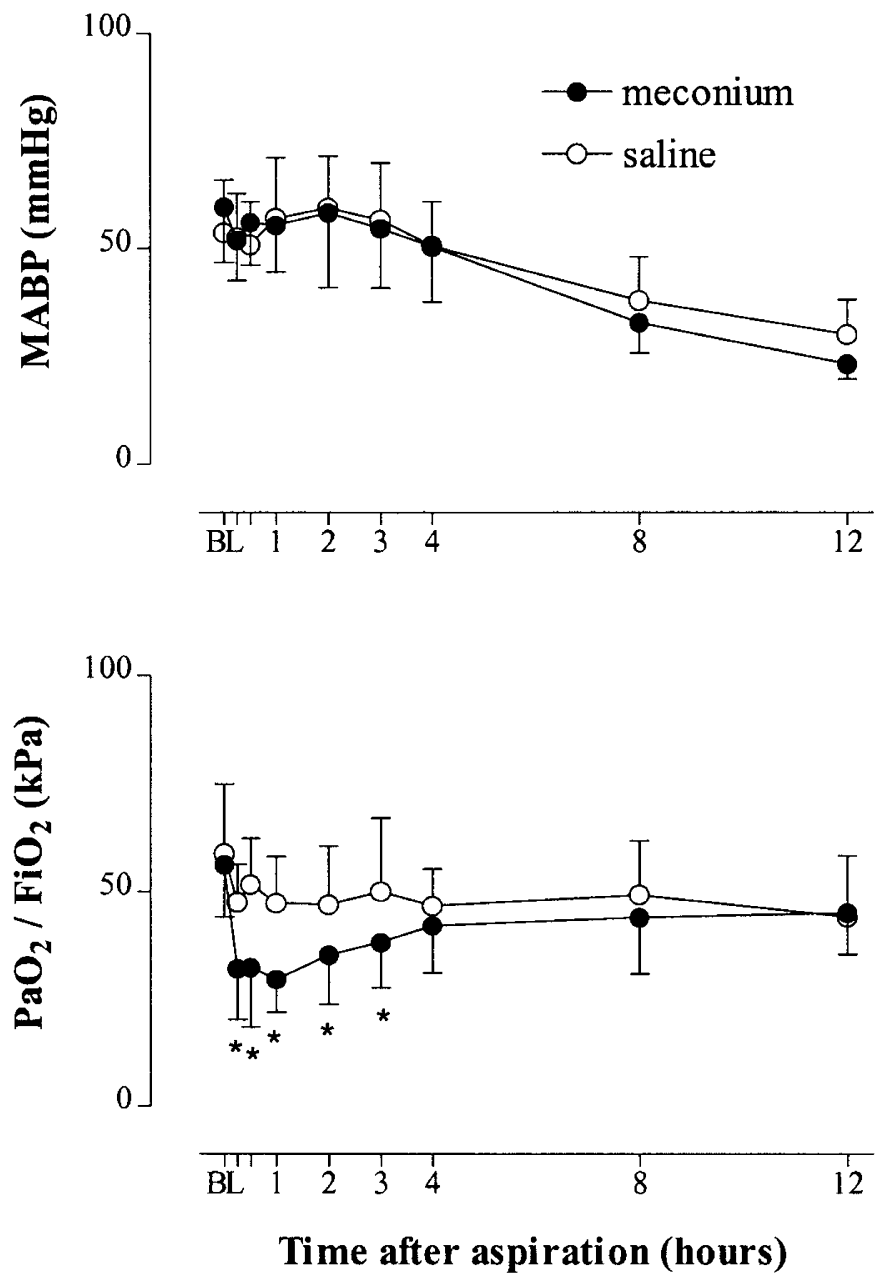

Figure 1. Mean arterial blood pressure (MABP) and arterial oxygenation index $\left(\mathrm{PaO}_{2} / \mathrm{FiO}_{2}\right)$ in newborn piglets after unilateral intrapulmonary instillation of meconium $(n=16)$ or saline $(n=15)$. Mean (SD).

Meconium instillation was associated with increased BAL fluid total cell count ipsilaterally (Table 2). A majority of these cells were neutrophils. BAL fluid protein concentration was increased after intrapulmonary meconium when compared with saline lungs, but no significant difference to the meconium noninstilled lungs was found (Table 2). Despite a tendency toward elevated values in the meconium-instilled lungs, TNF- $\alpha$ concentration in BAL fluid was similar in all studied groups (Table 2). Saline administration had no significant effect on these parameters. There were no correlations $(p>$ 0.05 ) between the BAL total cell or neutrophil count and protein or TNF- $\alpha$ concentration in any of the studied groups.

The catalytic activity of $\mathrm{PLA}_{2}$, measured from BAL fluid and lung tissue, was increased locally in the meconiuminstilled lungs, when compared with the noninstilled meconium lungs, and also in BAL fluid from the contralateral lungs ( $t$ test between noninstilled lungs, $p=0.0052$ ). Lung tissue $\mathrm{PLA}_{2}$ group-I and group-II concentrations were similarly elevated in the meconium-instilled lungs, group-I also in the noninstilled meconium lungs (Table 3 ). Saline instillation had no effect on the $\mathrm{PLA}_{2}$ activity or concentrations. The lung tissue catalytic activity or concentrations of $\mathrm{PLA}_{2}$ did not relate 
Table 1. Wet/dry lung weight ratio, histological lung injury score, alveolar septal diameter ( $\mu m$ ) and myeloperoxidase (MPO) activity (units $/ \mathrm{mg}$ prot) in newborn piglets $12 \mathrm{~h}$ after unilateral intrapulmonary instillation of meconium $(\mathrm{n}=9)$ or saline $(\mathrm{n}=8)$. Mean \pm SD (range)

\begin{tabular}{|c|c|c|c|c|}
\hline & $\begin{array}{l}\text { Wet/dry lung weight } \\
\text { ratio }\end{array}$ & $\begin{array}{l}\text { Histological lung } \\
\text { injury score }\end{array}$ & $\begin{array}{l}\text { Alveolar septal } \\
\text { diameter }\end{array}$ & MPO activity \\
\hline \multicolumn{5}{|l|}{ Meconium } \\
\hline Instilled lung & $\begin{array}{c}5.5 \pm 0.4 * \\
(5.0-6.3)\end{array}$ & $\begin{array}{c}7.6 \pm 1.7 * \dagger \\
\quad(5-10)\end{array}$ & $\begin{array}{l}7.5 \pm 1.9 \\
(4.3-10.6)\end{array}$ & $\begin{array}{c}0.79 \pm 0.22 * \dagger \\
(0.35-1.07)\end{array}$ \\
\hline Non-instilled lung & $\begin{array}{c}5.0 \pm 0.5 \\
(4.6-5.9)\end{array}$ & $\begin{array}{c}0.6 \pm 1.0 \\
\quad(0-3)\end{array}$ & $\begin{array}{l}6.9 \pm 2.8 \\
(3.5-12.8)\end{array}$ & $\begin{array}{c}0.45 \pm 0.19 \\
(0.25-0.79)\end{array}$ \\
\hline \multicolumn{5}{|l|}{ Saline } \\
\hline Instilled lung & $\begin{array}{l}5.1 \pm 0.2 \\
(4.8-5.4)\end{array}$ & $\begin{array}{c}0.8 \pm 0.9 \\
(0-2)\end{array}$ & $\begin{array}{l}7.9 \pm 2.6 \\
(4.7-11.9)\end{array}$ & $\begin{array}{l}0.51 \pm 0.17 \\
(0.32-0.77)\end{array}$ \\
\hline Non-instilled lung & $\begin{array}{c}5.0 \pm 0.3 \\
(4.6-5.4)\end{array}$ & $\begin{array}{c}0.9 \pm 2.1 \\
\quad(0-6)\end{array}$ & $\begin{array}{l}6.7 \pm 1.6 \\
(5.1-10.0)\end{array}$ & $\begin{array}{c}0.43 \pm 0.09 \\
(0.33-0.56)\end{array}$ \\
\hline & Group, $p=0.173$ & Group, $p<0.001$ & Group, $p=0.923$ & Group, $p=0.045$ \\
\hline & Side, $p<0.001$ & Side, $p<0.001$ & Side, $p=0.131$ & Side, $p<0.001$ \\
\hline & Interaction, $p=0.006$ & Interaction, $p<0.001$ & Interaction, $p=0.608$ & Interaction, $p=0.016$ \\
\hline
\end{tabular}

$* p<0.05$ vs. contralateral lung.

$\dagger p<0.05$ vs. saline instilled lung.

Table 2. Total cell count $\left(\times 10^{6} / \mathrm{L}\right)$, polymorphonuclear neutrophils $(P M N)(\%)$, protein $(\mathrm{g} / \mathrm{L})$ and tumor necrosis factor alfa $($ TNF- $\alpha)$ concentration $(\mathrm{pg} / \mathrm{ml})$ in bronchoalveolar lavage fluid of newborn piglets $12 \mathrm{~h}$ after unilateral intrapulmonary instillation of meconium $(\mathrm{n}=7)$ or saline $(\mathrm{n}=7)$. Mean $\pm S D$ (range)

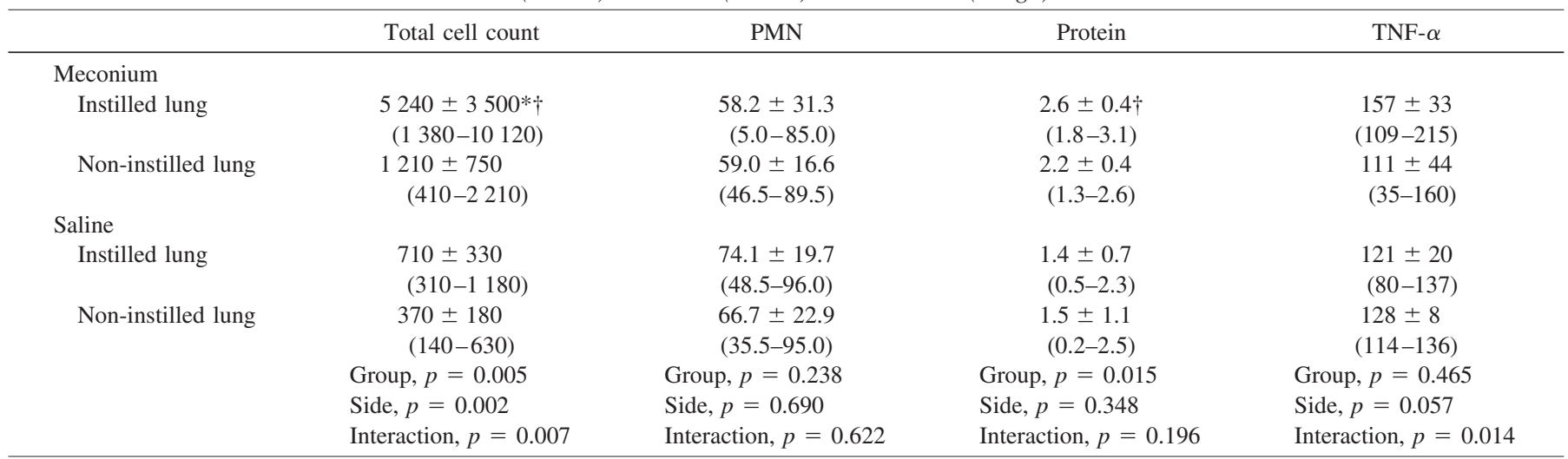

$* p<0.05$ vs. contralateral lung.

$\dagger p<0.05$ vs. saline instilled lung.

to the injury score or wet/dry-ratio, and similarly the bronchoalveolar $\mathrm{PLA}_{2}$ activity had no correlation to the cell count or protein or TNF- $\alpha$ concentrations.

\section{DISCUSSION}

In experimental meconium aspiration, inflammatory lung changes with ultrastructural signs of cellular injury have been observed within $6 \mathrm{~h}(7,11,21)$, with a maximum at 12 to $48 \mathrm{~h}$ after exposure (6). In contrast to experimental acid aspiration with marked generalized inflammatory response and significant lung injury manifesting as early as $3 \mathrm{~h}$ after instillation (14, 15 ), our present data suggest that these alterations are and remain mainly local, restricted to areas of meconium contamination. Since the meconium concentration of $65 \mathrm{mg} / \mathrm{mL}$, used in the present study, clinically corresponds to thick meconium in amniotic fluid, and after bilateral instillation induces severe persistent hypoxemia and progressive vascular hypertension in neonatal lungs (22), it is apparent that generalized pulmonary inflammatory reaction unlikely has a significant contribution to the pathogenesis of the clinical MAS. The early period of hypoxemia even after unilateral meconium insufflation may be a reflection of an initial ventilation/perfusion mismatch, frequently associated with pulmonary surge of smooth muscle contracting agents, like thromboxane $\mathrm{A}_{2}$, which may increase the resistance of the lung vascular bed and airways $(9,22,23)$.

Influx of neutrophils into the airspaces is a consistent feature of acute lung injury after various direct and nondirect insults $(8,12,13)$, as also evident in the meconium-contaminated lungs in our study. The mechanism underlying the local meconium-induced neutrophil migration is still unclear, but is supposedly triggered through stimulation of alveolar macrophages by constituents of meconium (10). Furthermore, in contrast to acid aspiration, the previously observed meconium- induced up-regulation of adhesion receptors may occur only locally $(10,15)$. Human meconium itself appears to have some neutrophil chemotactic activity, presumably due to the presence of potently chemotactic cytokines, such as IL-8 (24). Aspirated meconium may further induce intrapulmonary production of proinflammatory cytokines and prostaglandins $(25,26)$. Our results however indicate that alveolar TNF- $\alpha$ release is not significantly increased in the meconium-contaminated lungs. Thus, although TNF- $\alpha$ is a potent activator of neutrophils and 
Table 3. Catalytic activity of phospholipase $A_{2}\left(C A-P L A_{2}\right)$ (units/liter) in bronchoalveolar lavage (BAL) fluid supernatant and lung tissue, and lung tissue PLA 2 group-I and group-II concentrations $\left(P L A_{2}-I\right.$ and PLA $\left.-I I\right)(n g / m l)$ in newborn piglets $12 \mathrm{~h}$ after unilateral intrapulmonary instillation of meconium $(\mathrm{n}=9$ for lung tissue, $\mathrm{n}=7$ for BAL) or saline $(\mathrm{n}=8$ for lung tissue. $\mathrm{n}=7$ for BAL). Mean \pm $S D$ (range)

\begin{tabular}{|c|c|c|c|c|}
\hline & CA-PLA2 (BAL fluid) & $\begin{array}{l}\text { CA-PLA2 } \\
\text { (lung tissue) }\end{array}$ & PLA2-I & PLA2-II \\
\hline \multicolumn{5}{|l|}{ Meconium } \\
\hline Instilled lung & $\begin{array}{l}401 \pm 91 * \dagger \\
(289-566)\end{array}$ & $\begin{array}{c}379 \pm 140 * \dagger \\
(235-667)\end{array}$ & $\begin{array}{c}1511 \pm 246^{*} \dagger \\
(1120-1930)\end{array}$ & $\begin{array}{c}12.2 \pm 3.3^{* \dagger} \dagger \\
(8.0-18.0)\end{array}$ \\
\hline Non-instilled lung & $\begin{array}{r}15.3 \pm 5.2 \ddagger \\
(9.4-23.0)\end{array}$ & $\begin{array}{c}10.6 \pm 1.6 \\
(8.6-13.1)\end{array}$ & $\begin{array}{c}48.2 \pm 33.0 \ddagger \\
(8.7-94.0)\end{array}$ & $\begin{array}{c}1.5 \pm 0.7 \\
(0.5-2.6)\end{array}$ \\
\hline \multicolumn{5}{|l|}{ Saline } \\
\hline Instilled lung & $\begin{array}{l}8.3 \pm 6.3 \\
(0.4-17.4)\end{array}$ & $\begin{array}{l}9.9 \pm 1.1 \\
(7.6-10.9)\end{array}$ & $\begin{array}{r}18.6 \pm 30.7 \\
(0.9-93.0)\end{array}$ & $\begin{array}{r}1.3 \pm 0.5 \\
(0.1-1.7)\end{array}$ \\
\hline Non-instilled lung & $\begin{array}{c}4.8 \pm 4.0 \\
(0.5-12.7)\end{array}$ & $\begin{array}{c}9.7 \pm 1.6 \\
(7.6-12.8)\end{array}$ & $\begin{array}{r}10.8 \pm 11.3 \\
(0.6-31.0)\end{array}$ & $\begin{array}{c}1.4 \pm 0.3 \\
(1.0-1.8)\end{array}$ \\
\hline & Group, $p<0.001$ & Group, $p<0.001$ & Group, $p<0.001$ & Group, $p<0.001$ \\
\hline & Side, $p<0.001$ & Side, $p<0.001$ & Side, $p<0.001$ & Side, $p<0.001$ \\
\hline & Interaction, $p<0.001$ & Interaction, $p<0.001$ & Interaction, $p<0.001$ & Interaction, $p<0.001$ \\
\hline
\end{tabular}

may up-regulate neutrophil/endothelial adhesion receptors, it is probably not markedly responsible for the early local extravasation and accumulation of leukocytes within the alveolar spaces $(8,12)$. Previous experimental data indeed suggest that pulmonary TNF- $\alpha$ synthesis and release is time-dependent and peaks only at $24 \mathrm{~h}$ after meconium insult (25).

A bulk of clinical and experimental evidence indicates that neutrophils, when stimulated, are involved in the pathogenesis of the acute lung injury of various origin (8). Activated neutrophils release a wide variety of mediators, including reactive oxygen metabolites, cytokines and proteolytic enzymes, which may play an important role in the alveolocapillary injury with subsequent protein leak and edema formation $(8,12)$. Proteinaceous exudation into the alveolar spaces can further inactivate the pulmonary surfactant, decrease the lung compliance and intensify the respiratory failure $(6,27)$. On the other hand, since neutrophils may also migrate into the alveolar spaces without substantially altering the permeability of the lung epithelial barrier (28), the precise role of invading neutrophils in the pathogenesis of meconium-induced lung tissue injury still remains unclear. Alternatively, aspirated meconium may directly cause damage of the respiratory epithelium and thereby significantly increase the alveolar epithelial permeability to protein. Previous data indeed showed morphologic evidence of epithelial and endothelial injury already at $6 \mathrm{~h}$ after meconium instillation in piglets (21).

A number of observations have suggested that phospholipiddegrading enzyme, $\mathrm{PLA}_{2}$ plays an exacerbating role in the pathogenesis of acute inflammatory lung injury (29-31). PLA 2 -induced lipolysis can generate biologically active mediators, like lysophospholipids and FFA $(8,32)$, which may induce both damage to the alveolocapillary membrane and intrapulmonary sequestration of neutrophils (33). In accordance to findings in humans and experimental models with acute lung injury, we found elevated catalytic activity of $\mathrm{PLA}_{2}$ in the bronchoalveolar fluid from the meconium-instilled lungs (30,
31, 34). This enzyme may have been released from the activated neutrophils and macrophages accumulated in the alveolar space, or may be produced endogenously in the fixed pulmonary cells. Alternatively, human meconium is known to contain high concentrations of pancreatic (group-I) $\mathrm{PLA}_{2}$ that may, similar to intratracheal $\mathrm{PLA}_{2}$ group-II (synovial) administration, induce acute functional and morphologic alterations in the air spaces $(21,29,33)$. Pancreatic PLA 2 is further identified to be present in lung tissue and may additionally induce group-II $\mathrm{PLA}_{2}$ secretion that may at least partly explain the high enzyme concentrations in the meconium-instilled lungs (34, 35). Although the possibility of some contamination of the noninstilled lungs with meconium cannot be totally ruled out and the conclusive evidence of the pathogenetic role of $\mathrm{PLA}_{2}$ still remains unsettled, the observed challenge of the meconium-instilled lung with high activity of PLA $\mathrm{P}_{2}$, both exogenous and endogenous, may contribute to the local tissue injury and surfactant dysfunction after meconium aspiration also in neonatal lungs $(4,34,36)$.

Treatment of meconium-induced respiratory dysfunction with corticosteroids, potent anti-inflammatory agents, has yielded conflicting results (37-40). Despite of some improvement in oxygenation and hemodynamics after experimental meconium instillation, corticosteroid treatment does not seem to have any clear effect on the inflammatory reaction in the lung tissue (39). This further strengthens the present finding of lacking generalized pulmonary inflammatory injury after meconium insult. However, since local inflammatory lung injury after meconium instillation is significant, combined obstetric and pediatric suctioning of the airways remains as a critically important therapeutic approach in deliveries with meconium-stained amniotic fluid (2). Once meconium has entered the lungs, treatments aimed to ameliorate the local pulmonary tissue damage, such as intratracheal surfactant lavage, might be more beneficial than systemic anti-inflammatory treatments. 


\section{CONCLUSION}

In conclusion, meconium instillation induces severe localized lung inflammation, but significant generalized lung injury is lacking. Thus, the extension of the localized effects in the lungs, and hence the amount of aspirated meconium, seem to be critical in the pathogenesis of MAS, and the therapeutic efforts should be directed accordingly.

Acknowledgments. The authors thank Ms. Kaija Laine for her technical assistance and Mr. Hans Helenius, MSc, for his help in statistical analyses.

\section{REFERENCES}

1. Cleary GM, Wiswell TE 1998 Meconium-stained amniotic fluid and the meconium aspiration syndrome: An update. Pediatr Clin North Am 45:511-529

2. Wiswell TE, Bent RC 1993 Meconium staining and the meconium aspiration syndrome: Unresolved issues. Pediatr Clin North Am 40:955-981

3. Tran N, Lowe C, Sivieri EM, Shaffer TH 1980 Sequential effects of acute meconium obstruction on pulmonary function. Pediatr Res 14:34-38

4. Clark DA, Nieman GF, Thompson JE, Paskanik AM, Rokhar JE, Bredenberg CE 1987 Surfactant displacement by meconium free fatty acids: An alternative explanation for atelectasis in meconium aspiration syndrome. J Pediatr 110:765-770

5. Moses D, Holm BA, Spitale P, Liu M, Enhorning G 1991 Inhibition of pulmonary surfactant function by meconium. Am J Obstet Gynecol 164:477-481

6. Davey AM, Becker JD, Davis JM 1993 Meconium aspiration syndrome: Physiological and inflammatory changes in a newborn piglet model. Pediatr Pulmonol 16:101-108

7. Tyler DC, Murphy J, Cheney FW 1978 Mechanical and chemical damage to lung tissue caused by meconium aspiration. Pediatrics 62:454-459

8. Pittet JF, Mackersie RC, Martin TR, Matthay MA 2051997 Biological markers of acute lung injury: Prognostic and pathogenetic significance. Am J Respir Crit Care Med 155:1187-1119

9. Metz C, Sibbald WJ 1991 Anti-inflammatory therapy for acute lung injury. A review of animal and clinical studies. Chest 100:1110-1119

10. Kojima T, Hattori K, Fujiwara T, Sasai-Takedatsu M, Kobayashi Y 1994 Meconiuminduced lung injury mediated by activation of alveolar macrophages. Life Sci $54: 1559-1562$

11. Soukka H, Rautanen M, Halkola L, Kero P, Kääpä P 1997 Meconium aspiration induces ARDS-like pulmonary response in lungs of ten-week-old pigs. Pediatr Pulmonol 23:205-211

12. Fujishima S, Aikawa N 1995 Neutrophil-mediated tissue injury and its modulation. Intensive Care Med 21:277-285

13. Strieter RM, Kunkel SL 1994 Acute lung injury: The role of cytokines in the elicitation of neutrophils. J Investig Med 42:640-651

14. Goldman G, Welbourn R, Kobzik L, Valeri CR, Shepro D, Hechtman HB 1990 Tumor necrosis factor- $\alpha$ mediates acid aspiration-induced systemic organ injury. Ann Surg 212:513-520

15. Goldman G, Welbourn R, Kobzik L, Valeri CR, Shepro D, Hechtman HB 1995 Neutrophil adhesion receptor CD18 mediates remote but not localized acid aspiration injury. Surgery 117:83-89

16. Grisham MB, Benoit JN, Granger DN 1990 Assessment of leukocyte involvement during ischemia and reperfusion of intestine. Methods Enzymol 186:729-742

17. Shakir KM 1981 Phospholipase $A_{2}$ activity of post-heparin plasma: a rapid and sensitive assay and partial characterization. Anal Biochem 114:64-70
18. Schädlich HR, Bühler M, Beger HG 1987 Improved method for the determination of phospholipase $\mathrm{A}_{2}$ catalytic activity concentration in human serum and ascites. J Clin Chem Clin Biochem 25:505-509

19. Nevalainen TJ, Kortesuo PT, Rintala E, Märki F 1992 Immunochemical detection of group I and group II phospholipases $\mathrm{A}_{2}$ in human serum. Clin Chem 38:1824-1829

20. Santavuori SA, Kortesuo PT, Eskola JU, Nevalainen TJ 1991 Application of a new monoclonal antibody for time-resolved fluoroimmunoassay of human pancreatic phospholipase $\mathrm{A}_{2}$. Eur J Clin Chem Clin Biochem 29:819-826

21. Holopainen R, Aho H, Laine J, Peuravuori H, Soukka H, Kääpä P 1999 Human meconium has high phospholipase $\mathrm{A}_{2}$ activity and induces cellular injury and apoptosis in piglet lungs. Pediatr Res 46:626-632

22. Holopainen R, Soukka H, Halkola L, Kääpä P 1998 Meconium aspiration induces a concentration-dependent pulmonary hypertensive response in newborn piglets. Pediatr Pulmonol 25:107-113

23. Soukka H, Viinikka L, Kääpä P 1998 Involvement of thromboxane $A_{2}$ and prostacyclin in the early pulmonary hypertension after porcine meconium aspiration. Pediatr Res 44:838-842

24. de Beufort AJ, Pelikan DMV, Elferink JGR, Berger HM 1998 Effect of interleukin 8 in meconium on in-vitro neutrophil chemotaxis. Lancet 352:102-105

25. Vidyasagar D, Bhat R, Uhal B, Navale S, Zagariya A 1999 The TNF- $\alpha$, IL-1- $\beta$, IL-6, IL-8, IFN- $\gamma$, PGE-2 and IL-10 expression in meconium aspirated newborn lungs. Pediatr Res 45:325A

26. Jones CA, Cayabyab RG, Kwong KYC, Stotts C, Wong B, Hamdan H, Minoo P, deLemos RA 1996 Undetectable interleukin (IL)-10 and persistent IL-8 expression early in hyaline membrane disease: A possible developmental basis for the predisposition to chronic lung inflammation in preterm newborns. Pediatr Res 39:966-975

27. Cleary GM, Antunes MJ, Ciesielka DA, Higgins ST, Spitzer AR, Chander A 1997 Exudative lung injury is associated with decreased levels of surfactant proteins in a rat model of meconium aspiration. Pediatrics 100:998-1003

28. Martin TR, Pistorese BP, Chi EY, Goodman RB, Matthay MA 1989 Effect of leukotriene $\mathrm{B}_{4}$ in the human lung. Recruitment of neutrophils into the alveolar space without a change in protein permeability. J Clin Invest 84:1609-1619

29. Edelson JD, Vadas P, Villar J, Mullen JBM, Pruzanski W 1991 Acute lung injury induced by phospholipase A2. Structural and functional changes. Am Rev Respir Dis 143:1102-1109

30. Kim DK, Fukuda T, Thompson BT, Cockrill B, Hales C, Bonventre JV 1995 Bronchoalveolar lavage fluid phospholipase $\mathrm{A}_{2}$ activities are increased in human adult respiratory distress syndrome. Am J Physiol 269:L109-118

31. Furue S, Kuwabara K, Mikawa K, Nishina K, Shiga M, Maekawa N, Ueno M, Chikazawa Y, Ono T, Hori Y, Matsukawa A, Yoshinaga M, Obara H 1999 Crucial role of group IIA phospholipase $\mathrm{A}(2)$ in oleic acid-induced acute lung injury in rabbits. Am J Respir Crit Care Med 160:1292-1302

32. Chang J, Musser JH, McGregor H 1987 Phospholipase $\mathrm{A}_{2}$ : Function and pharmacological regulation. Biochem Pharmacol 36:2429-2436

33. Niewoehner DE, Rice K, Duane P, Sinha AA, Gebhard R, Wangensteen D 1989 Induction of alveolar epithelial injury by phospholipase $A_{2}$. J Appl Physiol 66:261-267

34. Vadas P, Pruzanski W 1986 Role of secretory phospholipases A2 in the pathobiology of disease. Lab Invest 55:391-404

35. Kishino J, Ohara O, Nomura K, Kramer RM, Arita H 1994 Pancreatic-type phospholipase $\mathrm{A}_{2}$ induces group II phospholipase $\mathrm{A}_{2}$ expression and prostaglandin biosynthesis in rat mesangial cells. J Biol Chem 269:5092-5098

36. Holm BA, Keicher L, Liu M, Sokolowski J, Enhorning G 1991 Inhibition of pulmonary surfactant function by phospholipases. J Appl Physiol 71:317-321

37. Frantz ID, Wang NS, Thach BT 1975 Experimental meconium aspiration: Effects of glucocorticoid treatment. J Pediatr 86:438-441

38. Khan AM, Shabarek FM, Kutchback JW, Lally KP 1999 Effects of dexamethasone on meconium aspiration syndrome in newborn piglets. Pediatr Res 46:179-183

39. Soukka H, Halkola L, Aho H, Rautanen M, Kero P, Kääpä P 1997 Methylprednisolone attenuates the pulmonary hypertensive response in porcine meconium aspiration. Pediatr Res 42:145-150

40. Yeh TF, Srinivasan G, Harris V, Pildes RS 1977 Hydrocortisone therapy in meconium aspiration syndrome: A controlled study. J Pediatr 90:140-143 